\title{
The Dourmal of
}
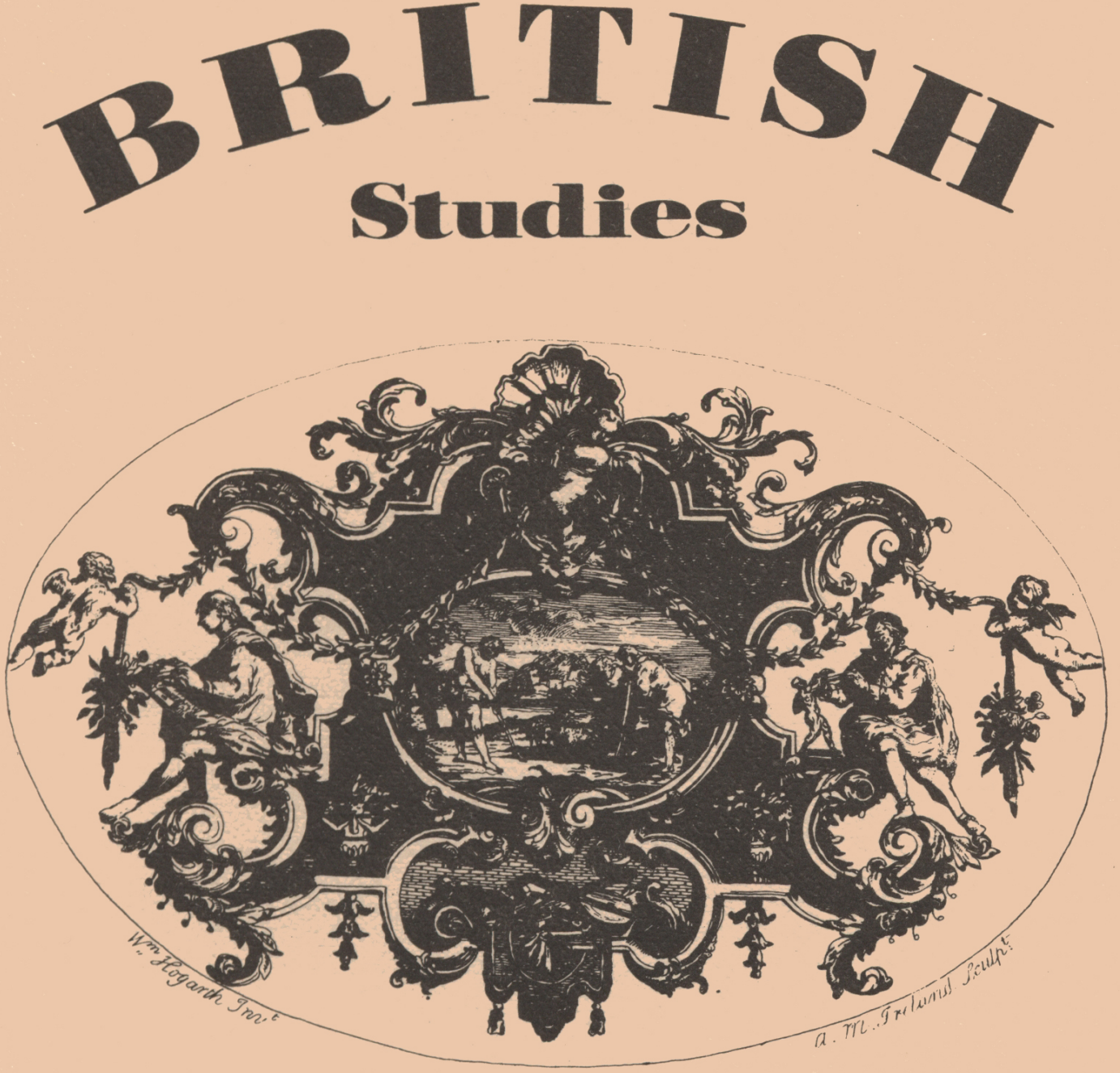

The Tankard

\section{FALL 1978}




\title{
From the library of Peter Stansky
}

EDITOR

ooper, Trinity College

EDITOR

MANAGER

McDonald

\section{BOARD OF ADVISORS}

H. J. Hanham, Massachusetts Institute of Technology Gertrude Himmelfarb, Graduate Center, City University of New York

Maurice Lee, Jr., Douglass College, Rutgers University F. M. Leventhal, Boston University

Bryce Lyon, Brown University

W. T. MacCaffrey, Harvard University
Helen F. Mulvey, Connecticut College

Jacob M. Price, University of Michigan

Bernard Semmel, State University of New York, Stony Brook

Barbara Shapiro, University of Califomia, San Diego

Robert A. Smith, Emory University

Robin W. Winks, Yale University

\section{OVERSEAS CORRESPONDENTS}

Harold Perkin, University of Lancaster

\author{
Barbara Harvey, Somerville College, Oxford
}

Keith Thomas, St. John's College, Oxford

\section{CONFERENCE ON BRITISH STUDIES}

\section{PRESIDENT}

Samuel C. McCulloch, University of California, Irvine

EXECUTIVE SECRETARY

Bentley B. Gilbert, University of Illinois at Chicago Circle

\author{
ASSOCIATE EXECUTIVE SECRETARY \\ Stephen Koss, Barnard College, Columbia University \\ RECORDING SECRETARY \\ Joel H. Wiener, City College of New York
}

TREASURER

Stuart Prall, Queens College, City University of New York

Fred A. Cazel, Jr., University of Connecticut Thomas Copeland, University of Massachusetts Jack Hexter (Former President), Yale University

\section{EXECUTIVE COMMITTEE}

Mary Keeler, Hood College

Madeline Robinton, City University of New York

Barbara Shapiro, University of California, San Diego
George B. Cooper, Trinity College L. P. Curtis, Jr., Brown University

\section{(NON-VOTING MEMBERS)}

Peter Marsh, Syracuse University

Michael Moore, Appalachian State University

\section{REGIONAL CONFERENCE REPRESENTATIVES}

\section{MIDATLANTIC}

John W. Wilkes, New York University

MIDWESTERN

Jacob Price, University of Michigan

NEW ENGLAND

David W. Trefford, University of Maine

\section{PACIFIC COAST}

Reba N. Soffer, California State University, Northridge

PACIFIC NORTHWEST

Ronald M. Meldrum, Washington State University

ROCKY MOUNTAIN

Neal Ferguson, University of Nevada, Reno

Frederick D. Schneider, Vanderbilt University

Annual subscription $\$ 8.00$ (two issues, Fall and Spring). Checks should be payable to the Journal of British Studies and directed to British Studies, Box 1315, Trinity College, Hartford, Connecticut 06106.

Correspondence concerning manuscripts should be addressed to the Editor, L. P. Curtis, Jr., Department of History, Brown University, Providence, R. I. 02912.
Information concerning membership in the Conference on British Studies may be obtained by writing to Barbara Malament, Department of History, Queen's College, C.U.N.Y., Flushing, New York 11367.

COVER: Rubbing from a tankard belonging to the Clare Market Artists Club, by William Hogarth. Reproduced by kind permission of the Lewis Walpole Library, Farmington, Connecticut. 


\section{The Jourmal of BRITISH Studies}

\section{Vol. XVII}

\section{Author}

MARTIN PIMSLER

R. S. GOTTFRIED

JOHN FLANINGAM

M. M. GOLDSMITH

FRED D. SCHNEIDER

HAROLD PERKIN

LOUIS B. ZIMMER

GERTRUDE HIMMELFARB

NoTES:

D. C. MOORE

R. W. DAVIS
No. 1

Fall 1977

\section{CONTENTS}

Title

Solidarity in the Medieval Village? The Evidence of Personal Pledging at Elton, Huntingdonshire

Population, Plague, and the Sweating Sickness: Demographic Movements in Late Fifteenth-Century England

The Occasional Conformity Controversy: Ideology and Party Politics, 1697-1711 38 Mandeville and the Spirit of Capitalism

The Habit of Deference: The Imperial Factor and the "University Question" in Upper Canada

Individualism versus Collectivism in Nineteenth-Century Britain: A False Antithesis

The 'Negative Argument' in J. S. Mill's Utilitarianism

Reply to Louis B. Zimmer on Mill's 'Negative Argument'

Some Thoughts on Thoroughness and Carefulness Suggested by Comparing the Reports of the Aylesbury Meeting of 24 February 1830 in The Times and the Bucks Gazette

Rebuttal 143

The Conference on British Studies at Trinity College, Hartford, Connecticut Copyright 1977 by the Conference on British Studies at Trinity College, Hartford, Connecticut. Printed in the U.S.A. at The Bond Press, Inc., Hartford, Connecticut. 


\section{CONTRIBUTORS TO THIS ISSUE}

JOHN FLANINGAM is an analyst with the Central Intelligence Agency and is researching anticlericalism in the Augustan Age.

MAURICE MARKS GOLDSMITH is Professor of Political Theory at the University of Exeter and has published Hobbes's Science of Politics as well as an article on Bernard Mandeville. He is currently a visiting fellow at Nuffield College, Oxford, where he intends to complete a book on Mandeville.

ROBERT S. GOTTFRIED is Assistant Professor of History at Douglass College, Rutgers University. He has published Epidemic Disease in Fifteenth Century England and articles in the Journal of Economic History and American Historical Review. He is finishing a book on the social and economic history of Bury St. Edmunds, 1290-1530, and beginning a book on the late medieval medical profession.

GERTRUDE HIMMELFARB is Professor of History at the Graduate Center, City University of New York. Her books include On Liberty and Liberalism; Victorian Minds; Darwin and the Darwinian Revolution; and Lord Acton. She is currently investigating the history of the idea of poverty.

HAROLD JAMES PERKIN is Professor, Head of the History Department, and Director of the Centre for Social History at the University of Lancaster. His books include The Origins of Modern English Society, 1780-1880; New Universities in the United Kingdom; Key Profession: History of the A.U.T.; The Age of the Railway; and The Age of the Automobile. His current research involves élites in British society since 1880, the structure and development of British society since 1880 , and international comparative higher education.

MARTIN PIMSLER is bibliographer and research associate at the Center for the Study of Ethics in the Professions at the Illinois Institute of Technology. His outside research is currently centered on the manorial documents of the Bacon Collection.

FRED D. SCHNEIDER is Professor of History at Vanderbilt University and has published several articles on politics and religion within an imperial context. He is currently studying the impact of imperialism: the British experience, in which the meaning of empire, authority, and societal change will loom large.

LOUIS B. ZIMMER is Associate Professor of History at Montclair State College. His article, "John Stuart Mill and Democracy, 1866-67," appeared in The Mill News Letter. He has just completed a study of Mill and Toryism and is currently investigating Mill's parliamentary politics during the 1860 s. 